\title{
A synopsis of the New World species of Drypetes section Drypetes (Putranjivaceae) with asymmetrical fruits, including description of a new species
}

\author{
Geoffrey A. Levin' \\ I Illinois Natural History Survey, Prairie Research Institute, University of Illinois at Urbana-Champaign, \\ 1816 South Oak Street, Champaign, Illinois 61820 \\ Corresponding author: Geoffrey A. Levin (levin1@illinois.edu)
}

Academic editor: LyubomirPenev | Received 23 July 2013 | Accepted 14 November 2013 | Published 22 November 2013

Citation: Levin GA (2013) A synopsis of the New World species of Drypetes section Drypetes (Putranjivaceae) with asymmetrical fruits, including description of a new species. PhytoKeys 29: 75-87. doi: 10.3897/phytokeys.29.6004

\begin{abstract}
A synopsis of the New World species of Drypetes (Putranjivaceae) with asymmetrical drupes is presented. The group consists of three species: $D$. alba, with two varieties, from the West Indies, D. gentryi from Mexico, and the newly described $D$. asymmetricarpa from Costa Rica. The new species can be distinguished from both its relatives by its longer fruiting pedicels. In addition, the new species differs from $D$. alba by its larger fruits, and from D. gentryi by having shorter staminate pedicels and stigmas borne on styles (rather than sessile). Lectotypes are designated for D. alba var. latifolia and D. incurva.
\end{abstract}

\section{Keywords}

Costa Rica, Drypetes, Mexico, Putranjivaceae, West Indies

\section{Introduction}

The genus Drypetes Vahl (Putranjivaceae) contains about 220 species of dioecious trees and shrubs, mostly of the Old World tropics. About 17 known species are found in the Americas, with the greatest diversity in the West Indies. However the Amazonian species are poorly studied and further research undoubtedly will yield many new species. In the classification of Pax and Hoffmann (1922), the most recent comprehensive 
treatment available for the genus, all but three of the American species belong to the pantropical section Drypetes based on their pistil consisting of a single carpel [although Pax and Hoffmann named this section Hemicyclia (Wight \& Arn.) Pax \& K. Hoffm., it contains D. glauca Vahl, the type of the genus, and therefore must be called Drypetes, as was pointed out by Airy Shaw (1969)]. The other three species have 2-carpellate pistils and belong to section Oligandrae Pax \& K. Hoffm. with 3-4(-7) stamens [D. lateriflora (Sw.) Krug \& Urb.] or section Sphragidia (Thwaites) Pax \& K. Hoffm. with 8-12(-50) stamens (D. brownii Standl. and D. guatemalensis Lundell); both of these sections also are pantropical. It is worth noting Drypetes has not been examined phylogenetically and the classification by Pax and Hoffmann (1922) may not reflect evolutionary relationships (Levin 1986).

Although no formal groups below the sectional level have been recognized among New World members of section Drypetes, there is a distinctive group of species with strongly asymmetrical drupes. In these species, the young ovary is symmetrical, as in other members of section Drypetes, but as the fruit develops the ovary grows faster on one side than the other, resulting in an oblique fruit apex with the stigma shifted to one side (Fig. 1B). As many as four species commonly have been recognized in this group. Here these are reduced to two species, one with two varieties, and a new species is described. The south Asian species Drypetes gardneri (Thwaites) Pax \& K. Hoffm., D. lanceolata (Thwaites) Pax \& K. Hoffm., and D. venusta (Wight) Pax \& K. Hoffm. have somewhat similar fruits but differ significantly from the American species in foliar and floral characters and probably are not closely related.

\section{Methods}

The study was based on the examination of specimens from the following herbaria: A, ARIZ, BM, CAS, CM, CR, DAV, F, G, G-DC, GH, GOET, HAJB, ILLS, K, LL, MEXU, MICH, MO, NY, P, SD, TEX, U, UC, UCR, and US. All cited specimens were seen by the author unless otherwise indicated. Identifications were made by comparison with the original descriptions and, when available, with the type material or photographs of types. Details of the flowers and fruits were examined under a stereoscopic microscope. All descriptions and data on flowering times, habitats, and distribution are based on the herbarium material examined. Countries in the Selected Specimens sections are listed alphabetically.

\section{Taxonomic treatment}

Key to the New World asymmetrical-fruited Drypetes

1 Fruiting pedicels (8-)10-15 mm long; Costa Rica....2. D. asymmetricarpa

- $\quad$ Fruiting pedicels 4-10 mm long; Mexico and West Indies 
- $\quad$ Staminate pedicels 3-6 mm long; drupes 9-10(-13) mm long; West Indies .

Type: Based on Drypetes alba Poit.

Drypetes sessiliflora Baill., Étude Euphorb., Atlas: 45. 1858, nom. illeg.

Type: Based on Drypetes alba Poit.

Drypetes alba var. genuina Müll. Arg. in DC., Prodr. 455. 1866, nom. inval.

Type: Based on Drypetes alba Poit.

Guatteria berteriana Spreng., Syst. Veg. (ed. 16) 2: 635. 1825.

Type: Puerto Rico, s.d., C. G. L. Bertero s.n. (holotype: $\mathrm{B}^{\dagger}$, isotype: TO n.v.).

Guatteria prinoides Spreng., Syst. Veg. (ed. 16) 2: 635. 1825.

Type: Haiti, s.d., C. G. L. Bertero s.n. (holotype: $\mathrm{B} \dagger$, isotypes: MO, TO n.v.).

Drypetes alba var. brevipes Müll. Arg. in DC., Prodr. 455. 1866.

Type: Puerto Rico, s.d., collector unidentified (holotype: G-DC).

Type. [Haiti.] Île de Tortue, s.d., A. Poiteau s.n. (holotype: P; isotype: G-DC).

Distribution. Haiti, Dominican Republic, Puerto Rico, and U.S. Virgin Islands.

Ecology. Forests from sea level to $1000 \mathrm{~m}$, primarily on calcareous soils, but in Puerto Rico also on serpentine-derived soils.

Phenology. Flowering primarily January to April, rarely as early as November. Fruiting February to August.

Conservation status. Least concern. Drypetes alba var. alba is widespread and likely secure in the Dominican Republic, Puerto Rico, and U.S. Virgin Islands. It may be vulnerable or endangered in Haiti due to extensive deforestation there; I have seen no specimens from Haiti collected later than 1929.

Selected specimens examined. HAITI. Southeast of St. Louis du Nord, 3 Apr 1928 (§ f), Leonard \& Leonard 14268 (CM, K, UC, US).

Dominican Republic. Loma Mala, near arroyo Guayabal, Maimón, 300-500 m, 16 Feb 1974 (fr), Liogier 21293 (F, K, MO).

Puerto Rico. Maricao Afuera, along Maricao River upstream from the fish hatch-

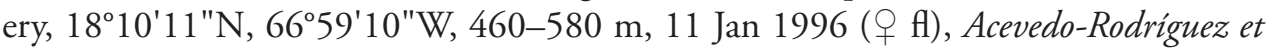
al. 7724 (K, US).

United States Virgin Islands. Saint Croix: Salt River bluffs, 6 Jul 1896 ( $\gtrsim \mathrm{fl})$, Ricksecker 462 (P). Saint John: Coral Bay Quarter, Bordeaux Mtn., east side, 11 Jan 
1992 (bud), Acevedo-Rodriguez \& Siaca 4710 (MO, US). Saint Thomas: s.d. (fr), Riedlé s.n. (F, P).

1b. Drypetes alba Poit. var. latifolia Griseb., Nachr. Königl. Ges. Wiss. GeorgAugusts-Univ. 1: 165. 1865.

Drypetes crocea Poit. var. latifolia (Griseb.) Müll. Arg., in A. P. de Candolle, Prodr. 15(2): 456. 1866.

Type: Based on Drypetes alba Poit. var. latifolia Griseb.

Drypetes latifolia (Griseb.) C.Wright, Anales Acad. Ci. Méd. Habana 7: 151. 1870.

Type: Based on Drypetes alba Poit. var. latifolia Griseb.

Koelera? serrata Maycock, Fl. Barbad. 38. 1830.

Type: No specimens cited or located [according to Stafleu and Cowan (1981),

Maycock probably made no herbarium; no type has ever been cited for this name].

Drypetes serrata (Maycock) Krug \& Urb., Bot. Jahrb. Syst. 15: 354. 1892.

Type: Based on Koelera serrata Maycock.

Drypetes serrulata Pax \& K.Hoffm. in H.G.A.Engler, Pflanzenr., IV, 147, XV: 267. 1922, nom. superfl.

Type: Based on Koelera serrata Maycock.

Drypetes glomerata Griseb., Abh. Königl. Ges. Wiss. Göttingen 7: 75. 1857.

Type: Guadeloupe. n.d., E. P. Duchassaing s.n. (holotype: GOET, photo plants. jstor.org/specimen/goet006390).

Drypetes glomerata Griseb. var. genuina Müll.Arg. in A.P.de Candolle, Prodr. 15(2):

454. 1866, nom. inval.

Type: Based on Drypetes glomerata Griseb.

Drypetes incurva Müll. Arg., Linnaea 32: 82. 1863.

Type: Cuba, prope Havana, 1833 (fr), $R$. de la Sagra 607 (lectotype, designated here: G-DC, duplicate: K).

Drypetes glomerata Griseb. var. olivacea Müll. Arg. in DC., Prodr. (DC.) 15(2): 454. 1866.

Type: Cuba, 1860-1864, C. Wright 1929 (holotype: G-DC, isotypes: BM, F, GH, $\mathrm{K}, \mathrm{MO}, \mathrm{NY})$.

Drypetes serrata (Maycock) Krug \& Urb.var. olivacea (Müll. Arg.) Krug \& Urb., Bot. Jahrb. Syst. 15: 355. 1892.

Type: Based on Drypetes glomerata Griseb. var. olivacea Müll. Arg.

Type. Cuba, occ., 1863 (fr), Wright 1927 (lectotype, designated here: GOET003380, photo plants.jstor.org/specimen/goet003380; duplicates: GH pro parte, K pro parte, MO pro parte, NY pro parte).

Distribution. Cuba, Jamaica, and the Lesser Antilles (Antigua, Guadeloupe, Martinique, Barbados).

Ecology. Forests on limestone and schist, from sea level to $1100 \mathrm{~m}$. 
Phenology. Flowering October to March. Fruiting December to July.

Conservation status. Least concern. Drypetes alba var. latifolia is widespread and probably secure in Cuba and Jamaica. Its status in the Lesser Antilles is difficult to assess because of a paucity of specimens.

Discussion. The plants I include in Drypetes alba have been segregated into species or varieties in various ways since the middle of the $19^{\text {th }}$ century (Grisebach 1857; 1865; Howard 1989; León and Alain 1953; Müller 1863; 1866; Pax and Hoffmann 1922). Characters that have been used include those of the leaves (petiole length and blade color, shape, and degree of marginal serration), staminate flowers (size, pedicel length, and stamen exsertion), and pistillate flowers/fruits (pedicel length relative to fruit length, style presence/absence, and fruit size). Most of the distinctions were based on observations of the one or two specimens available to earlier workers and these disappear when more specimens are examined. For example, Grisebach (1857), Müller (1866), and León and Alain (1953) distinguished D. alba (equivalent to var. alba is this treatment) from $D$. glomerata or its synonym $D$. serrata (here synonyms of var. latifolia) on the basis of the former having staminate flowers that are more than 1 $\mathrm{mm}$ long borne on longer pedicels and with exserted stamens in contrast to the latter having staminate flowers that are about $1 \mathrm{~mm}$ long borne on short pedicels and with included stamens. These differences appear to be an artifact of flower age: specimens with immature flowers, generally with the anthers indehiscent, were called D. glomerata or D. serrata, whereas those bearing fully mature flowers with dehiscent anthers were called D. alba. Pax and Hoffmann (1922) separated the same taxa using petiole length: 5-8 $\mathrm{mm}$ for $D$. alba vs. about $1 \mathrm{~cm}$ for $D$. serrulata, the superfluous name they used for what Grisebach and Müller called D. glomerata. In their concept, D. serrulata is restricted to the Lesser Antilles whereas $D$. alba is found throughout the Greater Antilles. Measurement of specimens shows that plants from the Lesser Antilles have slightly longer petioles $(7-12 \mathrm{~mm}$ vs. $5-10 \mathrm{~mm}$ ) than those from farther west, but clearly the variation is great and broadly overlapping. As I treat them, the two varieties have completely overlapping petiole lengths $(6-10 \mathrm{~mm}$ long for var. alba vs. $5-12 \mathrm{~mm}$ for var. latifolia). Howard (1989) reported that D. serrata, which he considered to be restricted to the Lesser Antilles, had larger fruits than D. alba of the Greater Antilles, but he did not provide comparative measurements. Although mature fruits of D. alba are rarely found on herbarium specimens, those I have seen are about $12-13 \mathrm{~mm}$ long throughout its range. Differences in leaf color, shape, and degree of marginal serration, alone or in combination, were used by Grisebach (1865) and Müller (1866) to describe new varieties based on single specimens, but these characters have been ignored by subsequent authors, presumably because they found, as I have, that these characters vary considerably even within individuals and certainly do not show consistent patterns.

The only character that seems consistently to differentiate Drypetes alba var. alba from var. latifolia is the presence of a style about $1 \mathrm{~mm}$ long in the former and its absence in the latter, the stigma being sessile. This character was first observed by Müller (1863) when he described $D$. incurva having a sessile stigma; he later noted the same condition in D. glomerata (Müller, 1866). I have found that all specimens from an 
individual island show the same condition and I have seen no intermediate specimens. Although this character is consistent geographically, in the absence of additional differences it seems too minor to support more than a varietal distinction. The distribution of the varieties is curious, with var. latifolia found both east and west of var. alba. DNA sequence data might elucidate this interesting distribution and clarify the evolutionary history of $D$. alba.

Grisebach (1865) based Drypetes alba var. latifolia on Wright 1927. It has long been recognized that this collection, like many of Wright's Drypetes collections, is a mixture of two species, in this case D. alba and D. lateriflora (Krug and Urban 1892; Pax and Hoffmann 1922). The material at GOET includes two sheets, both from the Grisebach Herbarium, and therefore presumably is the original material studied by Grisebach. These have the additional numbers 46 and 47 on the labels. The sheet labeled 46 (GOET 7917) consists of staminate and pistillate flowering branches of D. lateriflora and the sheet labeled 47 (GOET 3380) consists of a fruiting specimen of D. alba var. latifolia. Grisebach briefly described the leaves, staminate flowers, and fruits ("drupa"), thus he must have considered both sheets to be his new variety. In deciding which material best matches the protologue, the staminate flowers argue for GOET 7917 (D. lateriflora) and the fruits argue for GOET 3380 (D. alba var. latifolia). However Grisebach described the leaves as being subentire. The leaves of $D$. lateriflora on GOET 7917 are completely entire, whereas the leaves of D. alba var. latifolia on GOET 3380 are very shallowly crenulate-serrulate. The latter sheet thus better matches the protologue of D. alba var. latifolia and therefore I designate it as the lectotype.

Müller (1863) based Drypetes incurva on two collections, de la Sagra 607 and Wright 593, pro parte [this collection number includes material of $D$. incurva $(=D$. alba var. Latifolia) and D. lateriflora]. Later, Müller (1866) cited only de la Sagra 607 under D. incurva, placing Wright 593 under D. crocea Poit., a synonym of D. lateriflora. Based on the protologue of $D$. incurva, either sheet at G-DC could be chosen as the lectotype, but because it is not a mixed collection and therefore minimizes the potential for confusion, I designate de la Sagra 607 as the lectotype.

Selected specimens examined. CUBA. Camagüey: Banao, 300-500 m, Nov 1975 ( $\widehat{f} \mathrm{fl}$ ), Alvarez et al. 28778 (HAJB). Guantánamo: San Antonia del Sur, Puriales de Caujeri, Sierra de Purial cerca de Arroyo, 800 m, 30 May 1982 (fr), Bisse et al. 47259 (HAJB). Holguín: Sierra de Nipe, prope Río Piloto, 350 m, 16 Dec 1915 ( $\hat{f} \mathrm{f})$, Ekman 6694 (F, K, NY, U, US). Isla de la Juventud: Caleta Cocodrilos, $8 \mathrm{Mar}$ 1916 (fr), Britton et al. 15305 (CM, F, NY, US). Matanzas: Cienega, Peninsula de Zapata, montes al norte de Sto. Tomás, 19 Apr 1977 (fr), Bisse et al. 34469 (HAJB). Pinar del Río: La Guásima, Rangel, Jan 1950 (ㅇ fl), Liogier 1261 (GH, US). Sancti Spíritus: Trinidad Mountains, Arroyo Grande, 650-750 m, 11-12 Mar 1910 (fr), Britton \&Wilson 5459 (F, NY). Santiago de Cuba: Bayate, 20 Feb 1917 (fr), Ekman 8544 (F, K, LL, NY, U, US).

Jamaica. Trelawny: Boothe district, ca. 3 mi. north of Troy, 1600 m, 14 Mar 1955 ( fl, fr), Proctor 9956 (NY, US). 
Antigua and Barbuda. Antigua: environs de St. Jean, Dec 1902 ( $\widehat{f} \mathrm{f})$, Duss $80(\mathrm{NY})$.

Guadeloupe. Marie-Galante, bois de Folle-Anse, 1896 (fr), Duss 3628 (F, MO pro parte, NY, US pro parte).

Martinique. Morne Saint-Martin, pied de la montagne Pelée, 1878 ( $\widehat{\jmath}$ fl), Duss $50(\mathrm{NY})$.

\section{Drypetes asymmetricarpa G. A. Levin, sp. nov. urn:Isid:ipni.org:names:77134216-1 \\ http://species-id.net/wiki/Drypetes_asymmetricarpa}

Figure 1

Diagnosis. Differs from the other New World Drypetes species with asymmetrical fruits by its longer fruiting pedicels $[(8-) 10-15 \mathrm{~mm}$ vs. $4-10 \mathrm{~mm}]$; also differs from $D$. alba by its larger fruits $[12-18 \mathrm{~mm}$ vs. $9-10(-13) \mathrm{mm}]$, and from $D$. gentryi by having shorter staminate pedicels $(5-8 \mathrm{~mm}$ vs. $7-14 \mathrm{~mm}$ ) and stigmas borne on styles (vs. being sessile).

Type. Costa Rica. Puntarenas: Cove at NE base of peninsula, Punta Quepos $(3 \mathrm{~km}$

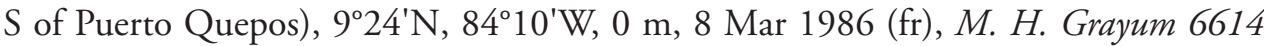
(holotype: $\mathrm{MO}$, isotypes: $\mathrm{CR}$ n.v., F).

Description. Trees 6-20 m, to $35 \mathrm{~cm}$ dbh; bark with longitudinal fissures; branches brown when young, becoming gray, glabrous or sparsely minutely puberulent with spreading hairs. Leaves: stipules $0.5 \times 0.5 \mathrm{~mm}$, deltate, puberulent; petiole 3-10 $\times 0.3-1$ $\mathrm{mm}$, glabrous; blade elliptic to lanceolate, straight or somewhat curved, 4-12 $\times 1.5-4.5$ $\mathrm{cm}$, base asymmetrical, acute, margins entire or minutely crenulate-serrulate, often undulate, apex attenuate, surfaces glabrous, $2^{\circ}$ veins $6-9 /$ side. Inflorescences axillary fascicles; staminate 25-40-flowered, bracts $0.5 \mathrm{~mm}$, puberulent, pedicels $5-8 \times 0.2 \mathrm{~mm}$, glabrous; pistillate (known only in fruit) 2-6-flowered, bracts $0.25 \times 0.25 \mathrm{~mm}$, deltate, puberulent, pedicels $(8-) 10-15 \times 0.4-0.8 \mathrm{~mm}$, glabrous. Staminate flowers: sepals 5-6, narrowly triangular to narrowly lanceolate, $1 \times 0.3 \mathrm{~mm}$, spreading and slightly incurved at apex, apex acute, margins ciliate, abaxial surface glabrous except puberulent at apex, adaxial surface densely to sparsely puberulent; stamens $5(-6)$, irregularly alternate and opposite sepals, filaments $1.5-2 \mathrm{~mm} \times 0.1 \mathrm{~mm}$, glabrous, anthers $0.4-0.5 \times 0.4-0.5$ $\mathrm{mm}$, glabrous, latrorse; disc lobed between stamens, densely puberulent. Pistillate flowers unknown, but remnant sepals (below fruits) ovate-elliptic, $1.5 \times 0.6 \mathrm{~mm}$, apex acute and slightly incurved, abaxial surface glabrous, adaxial surface densely puberulent; disc annular, densely puberulent; ovary unknown; style becoming subapical during fruit development, $0.5 \mathrm{~mm}$; stigma subreniform, $0.5 \times 1 \mathrm{~mm}$, glabrous. Drupes (immature) green, 1-carpellate, ovoid-globose, $12-18 \times 7-10 \times 6-8 \mathrm{~mm}$, apex strongly asymmetrical, sparsely to densely puberulent with very short hairs $(0.1 \mathrm{~mm})$. Seed 1 .

Etymology. The specific epithet refers to the strongly asymmetrical drupes, which are unique among Central American Drypetes. 


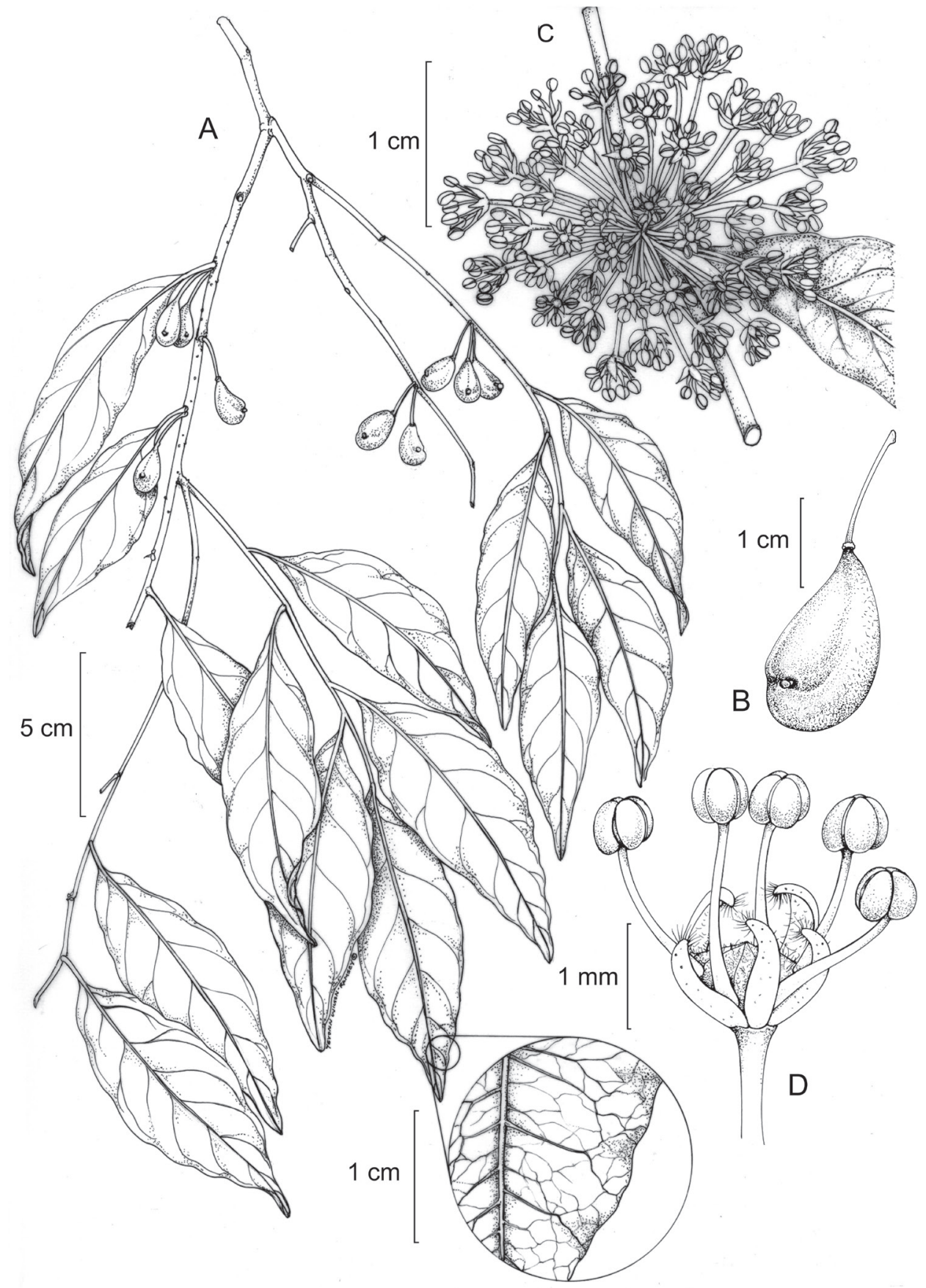

Figure I. Drypetes asymmetricarpa. A Fruiting branch (detail of venation) B Immature fruit C Staminate inflorescence D Staminate flower. (A-B from Grayum 6614, MO; C-D from Harmon 41, MO). 
Distribution. Known only from Costa Rica, where it is found from the north central part of the country to the central west coast. It may also be expected in extreme southern Nicaragua.

Ecology. Forests at elevations from sea level to $750 \mathrm{~m}$.

Phenology. Flowering January (possibly longer, but only a single flowering specimen known). Fruiting March to June (possibly longer as only immature fruits are known).

Conservation status. Probably of Least Concern. The range of Drypetes asymmetricarpa spans at least $200 \mathrm{~km}$. Although its habitat is highly fragmented, the species is found in Manuel Antonio National Park and near both Guanacaste and Rincón de la Vieja national parks.

Discussion. Drypetes asymmetricarpa was listed by Burger and Huft (1995) as D. sp. aff. D. alba and by González (2010) as Drypetes sp. 1 and sp. 2.

All the pistillate specimens studied have immature fruits, so their full size and color at maturity are unknown. The label on Hammel \& Trainer 17046, with fruits 9-11 $\times$ 7-8 $\times 6-7 \mathrm{~mm}$, says "fruits ca. 1/3 full size," but based on my experience with other species I suspect this overestimates the mature size.

Specimens examined. COSTA RICA. Alajuela: Cantón de Upala, Distrito Dos Ríos, $7.5 \mathrm{~km} \mathrm{NE}$ of town, between La Jabalina and the Río Cucaracho, $10^{\circ} 56^{\prime} \mathrm{N}$, 85¹9'W, 325 m, 4 Apr 1988 (fr), Herrera 1693 (F, ILLS, MO); Puntarenas: Cantón de Puntarenas, Distrito Monteverde, San Luis, finca de Chepe Rojas, al oeste del pueblo, $10^{\circ} 16^{\prime} \mathrm{N}, 84^{\circ} 50^{\prime} \mathrm{W}, 750$ m, 24 Jun 1988 (fr), Bello et al. 35 (F, ILLS, MO), Bello et al. 58 (F, ILLS, MO); Monteverde area from Santa Elena to San Luis, $10^{\circ} 16^{\prime} \mathrm{N}$, $84^{\circ} 50^{\prime} \mathrm{W}, 700$ m, 16 Jun 1988 (fr), Hammel \& Trainer 17046 (F, ILLS, MO); Parque Nacional Manuel Antonio, Playa Espadilla Sur. $9^{\circ} 24^{\prime} \mathrm{N}, 84^{\circ} 10^{\prime} \mathrm{W}, 1-100$ m. 2 Jan 1990 (ð̊ fl), Harmon 41 (MO).

\section{Drypetes gentryi Monach., Phytologia 3: 32. 1948, as "gentryii" http://species-id.net/wiki/Drypetes_gentryi}

Type. Mexico. Sinaloa: Capadero, Sierra Tacuichamona, rocky canyon under basaltic rim, 3500 ft., 13 Feb 1940 (fr), H. S. Gentry 5597 (holotype: NY, isotypes: ARIZ, $\mathrm{MICH}, \mathrm{MO})$.

Distribution. Western Mexico, in the Sierra Madre Occidental from near $27^{\circ} \mathrm{N}$ in Chihuahua and Sonora to about $19^{\circ} \mathrm{N}$ in Colima.

Ecology. Tropical deciduous forests at about 100-1100m.

Phenology. Flowering December-February. Fruiting December-June.

Conservation status. Least Concern. Drypetes gentryi is widespread in the lower elevations of the Sierra Madre Occidental.

Discussion. When Monachino (1948) described Drypetes gentryi, he examined only a single specimen. No other descriptions of the species have been published, so I provide here an expanded description: 
Trees 8-25 m, often with multiple trunks from near base, to $20-100 \mathrm{~cm} \mathrm{dbh}$; bark scaled and with longitudinal fissures; branches brown when young, becoming gray, minutely puberulent with spreading hairs, becoming glabrous. Leaves: stipules 0.5-0.6 × 0.7-1 mm, deltate, puberulent; petiole 6-12 × 0.7-1 mm, puberulent with spreading hairs or glabrous; blade elliptic to lanceolate, straight or somewhat curved, 4-15 × 1.5-4 cm, base asymmetrical, acute to narrowly obtuse, margins subentire to crenulate-serrulate, often undulate, apex attenuate, surfaces glabrous or very sparsely pubescent with appressed hairs especially near base, $2^{\circ}$ veins $6-9 /$ side. Inflorescences axillary fascicles; staminate 20-40-flowered, bracts $0.5 \times 0.5 \mathrm{~mm}$, deltate, puberulent, pedicels 7-14 × $0.2 \mathrm{~mm}$, glabrous; pistillate 1-6-flowered, bracts $0.5 \times 0.5 \mathrm{~mm}$, deltate, puberulent, pedicels $3-10 \times 0.4-0.5 \mathrm{~mm}$, puberulent when young, becoming glabrous. Staminate flowers: sepals $5(-6)$, linear to narrowly triangular, $1.2 \times 0.4 \mathrm{~mm}$, spreading and slightly incurved at apex, apex bluntly acute, margins ciliate, abaxial surface glabrous except puberulent at apex, adaxial surface puberulent; stamens 5(-6), mostly opposite sepals, filaments $1.6-2.2 \mathrm{~mm} \times 0.1 \mathrm{~mm}$, glabrous, anthers $0.8-1 \times 0.5-0.6 \mathrm{~mm}$, glabrous, latrorse; disc lobed between stamens, densely puberulent. Pistillate flowers: sepals 5, narrowly triangular to linear, $1-1.2 \times 0.3-0.4 \mathrm{~mm}$, spreading, entire, apex bluntly acute, abaxial surface glabrous to sparsely puberulent but densely puberulent at apex, adaxial surface densely puberulent; disc annular, densely puberulent; ovary densely puberulent; style absent; stigma apical at anthesis, becoming subapical during fruit development, subreniform, $0.8 \times 1.2 \mathrm{~mm}$, glabrous. Drupes (immature) green, 1-carpellate, obovoid, $12-15 \times 7-9 \times 6-8 \mathrm{~mm}$, apex strongly asymmetrical, densely puberulent with very short hairs $(0.1 \mathrm{~mm})$. Seed 1 .

The mature fruits are described as white (Bye 6066) or yellow (Bye et al. 12847), with the mesocarp juicy and both sweet and astringent (Bye et al. 12847). Spanish vernacular names include cortopico (Gentry 5597), palo masiso (Bye 9707), and tempisque (Bye 3401, Bye et al. 12847); in Tarahumara it is called bapible (Bye 3401) or kafe (Bye et al. 12847), and in Guarijio joyari (Felger et al. 94-56).

Selected specimens examined. MEXICO. Chihuahua: Mpio. Batopilas, north side of Barranca de Batopilas, along arroyo Samachique between Rio Batopilas and Tarahuamara village of Wimivo, 2709' N, 107³8'W, 900-1000 m, 30 May 1980 (fr), Bye 9707 (ARIZ, DAV, F, GH, ILLS, MEXU, MICH, MO, NY, SD, TEX, UCR, US); Colima: canyon near Rio Marabasco (Cihuatlan) bridge on road to Chacala, north of Santiago, 19 $17^{\prime} \mathrm{N}, 104^{\circ} 19^{\prime} \mathrm{W}, 200-250 \mathrm{~m}, 21$ Jan 1988 (fr), Levin \& Dice 1975 (MO, SD); Jalisco: canyon east of Highway $200 \mathrm{ca} .2 \mathrm{~km}$ eastsoutheast of Boca de Tomatlan, at bridge, 20 $03^{\prime} \mathrm{N}, 105^{\circ} 18^{\prime} \mathrm{W}, 100-200 \mathrm{~m}, 25 \mathrm{Jan}$ 1988 (ठ), Levin \& Dice 2001 (MO, SD); Sonora: Arroyo Gochico ca. $8 \mathrm{~km}$ E of San Bernardo, 2702'04"N, 108 04'07"W, 300 m, 31 Jan 1988 (ㅇ fl, fr) Levin et al. 2015 (MO, SD). 


\section{Acknowledgements}

I thank Jochen Heinrichs for providing high-resolution scans of specimens at GOET, and the staff of the other herbaria listed for providing access to the specimens in their care. Lynn Gillespie and three anonymous reviewers provided helpful comments on the manuscript. Figure 1 was prepared by Yevonn Wilson-Ramsey.

\section{References}

Airy Shaw HK (1969) Notes on Malesian and other Asiatic Euphorbiaceae. CII. New or noteworthy species of Drypetes Vahl. Kew Bulletin 23: 55-62. http://www.jstor.org/stable/4117000

Burger W, Huft M (1995) Flora Costaricensis, Family \#113. Euphorbiaceae. Fieldiana, Botany, ns 36: 1-169. http://www.biodiversitylibrary.org/item/20358

González J (2010) Euphorbiaceae. In: Hammel BE, Grayum MH, Herrera C, Zamora N (Eds) Manual de Plantas de Costa Rica, vol. V. Dicotiledoneas (Clusiaceae - Gunneraceae). Monographs in Systematic Botany from Missouri Botanical Garden 119: 290-394.

Grisebach AHR (1857) Systematische Untersuchungen Über die Vegetation der Karaiben, insbesondere Insel Guadeloupe. Abhandlungen der Königlichen Gesellschaft der Wissenschaften zu Göttingen 7: 151-286. http://www.biodiversitylibrary.org/item/109580

Grisebach AHR (1865) Diagnosen neuer Euphorbiaceen aus Cuba. Nachrichten von der Königlichen Gesellschaft der Wissenschaften und von der Georg-Augusts-Universität 1: 161-181. http://www.digizeitschriften.de/dms/resolveppn/?PPN=GDZPPN002510227

Howard RA (1989) Flora of the Lesser Antilles, Dicotyledoneae-part 2. Arnold Arboretum, Harvard Univ., Jamaica Plain, Massachusetts, 1-604.

Krug CWL, Urban I (1892) Additamenta ad cognitionem florae Indiae occidentalis. Botanische Jahrbücher für Systematik, Pflanzengeschichte und Pflanzengeographie 15: 286-437. http://www.biodiversitylibrary.org/item/674

León H, Alain H (1953) Flora de Cuba. Fernandez, Havana, 1-556.

Levin GA (1986) Systematic foliar morphology of Phyllanthoideae (Euphorbiaceae) III. Cladistic analysis. Systematic Botany 11:515-530. doi: 10.2307/2419031

Monachino JV (1948) Three new species of Drypetes. Phytologia 3: 32-35. http://www.biodiversitylibrary.org/item $/ 46705$

Müller J (1863) Euphorbiaceae. Vorläufige Mittheilungen aus dem für DeCandolle’s Prodromus bestimmten Manuscript über diese Familie. Linnaea 32: 1-126. http://www.biodiversitylibrary.org/item/10877

Müller J (1866) Euphorbiaceae. In: de Candolle AP (Ed) Prodromus systematis naturalis regni vegetabilis, vol. 15(2). Masson, Paris, 1-1286. http://www.biodiversitylibrary.org/item/7166

Pax F, Hoffmann K (1922) Euphorbiaceae-Phyllanthoideae-Phyllantheae. In: Engler A (Ed) Das Pflanzenreich, IV, 147 XV (Heft 81). 1-349. http://www.biodiversitylibrary.org/item/61957

Stafleu FA, Cowan RS (1981) Taxonomic literature, ed. 2, vol. III: Lh-O. Bohn, Scheltema, \& Holkema, Utrecht, Netherlands, 1-980. http://www.biodiversitylibrary.org/item/104137 


\section{Index to numbered collections}

Abbott, W.L. 2571, 2932 (alba var. alba)

Acevedo-Rodríguez, P. 4710, 4781, 7724 (alba var. alba)

Alvarez, A. 28778, 45576 (alba var. latifolia)

Areces, A. 25812 (alba var. latifolia)

Bello, E. 35, 58 (asymmetricarpa)

Bisse, J. 16899, 22625, 26478, 34469, 46192, 47203, 47259, 53290 (alba var. latifolia)

Britton, E.G. 5154 (alba var. alba)

Britton, N.L. 2457, 2748, 4128, 4208 (alba var. alba); 5459 (alba var. latifolia); 8104, 9676 (alba var. alba); 15305 (alba var. latifolia)

Bye, R.A. 3401, 3557, 3558, 3958, 6066, 9707, 12847 (gentryi)

Duke, J.A. 7350 (alba var. alba)

Duss, A. 50, 80 (alba var. latifolia); 3628 (alba var. latifolia and Drypetes glauca Vahl); 4142 (alba var. latifolia)

Eggers, H.F.A. 2612 (alba var. alba)

Ekman, E.L. 4146 (alba var. latifolia); 4179 (alba var. alba); 4543, 4568, 4838, 5006 (alba var. latifolia); 5528 (alba var. alba); 6694, 8544, 9764, 9913 (alba var. latifolia); 12160 (alba var. alba); 12462, 18213 (alba var. latifolia); H.3512, H.3870, H.4178, H.4179, H.5134, H.5528, H.6061, H.9614, H.12160 (alba var. alba)

Felger, R.S. 94-56, 97-118 (gentryi)

Gentry, A.H. 50716 (alba var. alba)

Gentry, H.S. 3618, 5597 (gentryi)

Grayum, M.H. 6614 (asymmetricarpa)

Haenke, T. 1605 (gentryi)

Hammel, B.E. 17046 (asymmetricarpa)

Harmon, W.E. (asymmetricarpa)

Harris, W. 7098 (alba var. latifolia)

Herrera, G. 1693 (asymmetricarpa)

Holdridge, L.R. 149 (alba var. alba)

Jack, J.G. 7809 (alba var. latifolia)

Jiménez Almonte, J. de J. 1981, 4360, 5058 (alba var. alba)

León, Bro. 6081, 11800 (alba var. latifolia)

Leonard, E.C. 11589, 14257, 14268, 15686 (alba var. alba)

Lesueur, D.H. 1419 (gentryi)

Levin, G.A. 1973, 1975, 2001, 2014, 2015 (gentryi)

Liogier, A.H. 1017, 1261, 1275, 2997, 5719 (alba var. latifolia); 10466, 10714, $10779,14325,15661,20858,21293,21600,22628,24490,24537,25846$, 26463, 26835 (alba var. alba)

Little, E.L., Jr. 13297, 13366 (alba var. alba)

Luna, A. 15 (alba var. latifolia)

McVaugh, R. 1647, 25404 (gentryi) 
Pérez J., L.A. 413 (gentryi)

Proctor, G.R. 9956 (alba var. latifolia)

Ricksecker, A.E. 462 (alba var. alba)

Sagra, R. de la 607 (alba var. latifolia)

Sanders, A.C. 1096 (gentryi)

Schiffino, J. 15 (alba var. alba)

Shafer, J.A. 3693, 4403 (alba var. latifolia)

Sintenis, P.E.E. 1502 (alba var. alba)

Stehlé, H. 416 (alba var. latifolia)

Valeur, E.J. 837 (alba var. alba)

Van Devender, T.R. 93-1381 (gentryi)

Wilson, P. 9287 (alba var. latifolia)

Wright, C. 498, 501 (alba var. alba and Drypetes lateriflora (Sw.) Krug \& Urb.); 593 (alba var. latifolia and D. lateriflora); 1112 (alba var. latifolia); 1927 (alba var. latifolia and D. lateriflora); 1928, 1929, 1929, 593b (alba var. latifolia)

Zanoni, T.A. 36401 (alba var. alba) 